Article

\title{
Linking Past and Present Land-Use Histories in Southern Amazonas, Peru
}

\author{
Daniel Plekhov 1,*(D), Parker VanValkenburgh ${ }^{2}$ D , Paul Abrams ${ }^{2}$, Amanda Cutler ${ }^{3}$, Justin Han ${ }^{1}$, \\ Alexis Jair Reátegui Díaz ${ }^{4}$, Bryn Sullivan ${ }^{5}$ and Steven Wernke ${ }^{6}$
}

1 Joukowsky Institute for Archaeology and the Ancient World, Brown University, Providence, RI 02912, USA; justin_han@brown.edu

2 Department of Anthropology, Brown University, Providence, RI 02912, USA; parker_vanvalkenburgh@brown.edu (P.V.); paul_abrams@brown.edu (P.A.)

3 Program in Science, Technology and Society, Brown University, Providence, RI 02912, USA; amanda_cutler@brown.edu

4 Independent Scholar, Pucallpa 25000, Peru; ajreategui@gmail.com

5 Independent Scholar, Santa Cruz, CA 95060, USA; bryn_sullivan@alumni.brown.edu

6 Department of Anthropology, Vanderbilt University, Nashville, TN 37235, USA; steven.a.wernke@vanderbilt.edu

* Correspondence: daniel_plekhov@brown.edu

check for updates

Citation: Plekhov, D.; VanValkenburgh, P.; Abrams, P.; Cutler, A.; Han, J.; Reátegui Díaz, A.J.; Sullivan, B.; Wernke, S. Linking Past and Present Land-Use Histories in Southern Amazonas, Peru. Remote Sens. 2021, 13, 2274. https:// doi.org $/ 10.3390 /$ rs13122274

Academic Editors: Jesse Casana and Elise Jakoby Laugier

Received: 9 April 2021

Accepted: 4 June 2021

Published: 10 June 2021

Publisher's Note: MDPI stays neutral with regard to jurisdictional claims in published maps and institutional affiliations.

Copyright: (C) 2021 by the authors. Licensee MDPI, Basel, Switzerland. This article is an open access article distributed under the terms and conditions of the Creative Commons Attribution (CC BY) license (https:// creativecommons.org/licenses/by/ $4.0 /)$.
Abstract: This paper analyzes remotely sensed data sources to evaluate land-use history within the Peruvian department of Amazonas and demonstrates the utility of comparing present and past land-use patterns using continuous datasets, as a complement to the often dispersed and discrete data produced by archaeological and paleoecological field studies. We characterize the distribution of ancient (ca. AD 1-1550) terracing based on data drawn from high-resolution satellite imagery and compare it to patterns of deforestation between 2001 and 2019, based on time-series Landsat data. We find that the patterns reflected in these two datasets are statistically different, indicating a distinctive shift in land-use, which we link to the history of Inka and Spanish colonialism and Indigenous depopulation in the 15th through 17th centuries AD as well as the growth of road infrastructure and economic change in the recent past. While there is a statistically significant relationship between areas of ancient terracing and modern-day patterns of deforestation, this relationship ultimately explains little $(6 \%)$ of the total pattern of modern forest loss, indicating that ancient land-use patterns do not seem to be structuring modern-day trajectories of land-use. Together, these results shed light on the long-term history of land-use in Amazonas and their enduring legacies in the present.

Keywords: agriculture; land-use; terraces; deforestation; Peru; remote sensing

\section{Introduction}

Amidst the mountainous topography of the Andes, Indigenous people have built agricultural terraces for millennia, for a diverse series of reasons-to mitigate against erosion, to manage irrigation systems, to expand planting surfaces, and to modify microclimatic conditions, among others [1-6]. It is also becoming increasingly clear that, just as they served multiple functions in the past, terraced landscapes in the Andes (as elsewhere) were constructed through prolonged, and often incremental, processes [7-10]. While many terrace systems seem to have been constructed and managed by small-scale communities, others appear to have been erected at the behest of expansive polities, such as the Wari and Inka, who employed them as tools of agricultural intensification and as elements of sovereign claims over landscapes and peoples [11,12].

Andean Indigenous terraced agriculture was significantly impacted by the Spanish Invasion of AD 1531-35 and its aftermath, after which the total area of terraced agricultural land significantly decreased [2] (pp. 183-184). Processes driving agricultural contraction 
differed by region, but much appears linked to the decimation of Indigenous populations following the Spanish invasion $[13,14]$. Other factors cited for the abandonment of agricultural terraces include the resettlement of communities; changes in crop regimes and subsistence strategies, with a greater reliance on lower elevation crops from Europe and on the raising of cattle; the adoption of new plowing technologies; the disruption of community social and labor organization; and climatic changes resulting from the Little Ice Age [15-21].

Today, agricultural terraces remain a persistent, though diminished, part of rural agricultural systems in the Andes as well as an iconic (and sometimes monumental) element of the region's archaeological landscapes [22,23]. Construction of new terraces appears to be rare, while disassembly (both intentional, for the sake of obtaining building materials or expanding pasture areas, and unintentional, through the cumulative effects of mechanized or oxen-driven plowing) is more common [24-26]. The continued abandonment of terraces, even as rural populations have increased, therefore attests to significant social, economic, and technological shifts and a new logic of land-use that differs from that in the past [27-30]. The introduction of Eurasian livestock to the Americas has, for example, had particularly notable consequences for land-use patterns in the long term, both through its environmental effects as well as its reorganization of labor and market forces [31,32]. However, the fact that many ancient terraces remain in use today also attests to their enduring capacity for controlling erosion, increasing soil depth, and managing hydrology. In many cases, studies have demonstrated that even abandoned terraces retain productive soils, thereby continuing to provide benefits and opportunities for modern-day communities [33-35].

Indeed, it is useful to avoid classifying terrace systems according to a simple binary of abandoned vs. in-use, for at least three reasons. First, due to long fallowing periods (particularly in upland regions, where they may last as long as 10 years), it can be difficult to distinguish abandoned terraces from those that remain in use, even when assessing their status using more proximate datasets than remotely sensed satellite imagery, e.g., $[10,18,28,36,37]$. Second, the actual use and maintenance of terrace systems is also non-binary, ranging along a continuum of maintenance and production, from very high-intensity, carefully maintained terraces of high value crops to low-intensity, low-input cultivation of cacti and other perennials on partially collapsed, eroded, even relict terraces [38]. Third, terrace systems often continue to be geomorphologically "active" agents even if they are not carefully maintained or used in agricultural cycles, providing ancillary services (and sometimes impediments) to the people, plants, and animals that live around them.

Land-use patterns in the Andes have demonstrably changed between the past and the present, but the difficulties involved with distinguishing ongoing terrace use from abandonment as well as the cyclical use and reuse of terraced landscapes can make it challenging to define precisely how these patterns have shifted over time. However, it remains important that we attempt to do so. Charting changes in land-use at large scales over the long term can generate important new data for understanding the processes and factors driving that change. As policy makers continue to look to Indigenous technologies as means of combating rural poverty, environmental degradation, and food insecurity, e.g., $[22,23,39-41]$, understanding what made ancient terraces viable in the past is essential for considering whether such technologies hold relevance for rural communities today.

One region where such assessments may be particularly productive is the southern portion of the Amazonas department, in northern Peru (Figure 1). As elsewhere in the Andes, landscapes in southern Amazonas bear evidence of a significant decline in the extent of agricultural terracing under cultivation after the Spanish invasion, from at least the late 16th century AD and perhaps beginning as early as the Late Horizon (Inka period, ca. AD 1470-1535). However, because rainfall in Amazonas is generally higher than in much of the Central and Southern Peruvian Andes, much of the region's natural vegetation is forested. Thus, Indigenous depopulation and terrace abandonment has resulted in significant reforestation of formerly cleared land over the past several centuries. Today, 
amidst economic and demographic growth, agricultural and pastoral production have increased, and new areas for cultivation and grazing have opened up in reforested areas. In the process, expansive areas of ancient terracing have been revealed, and much of this terracing is clearly identifiable in very high-resolution $(<5 \mathrm{~m})$ satellite imagery. These conditions mean that it is possible to employ analysis of satellite imagery in combination with field-based reconnaissance to carry out systematic and regional-scale evaluation of the distribution of ancient land-use in southern Amazonas and to assess how it compares to land-use patterns today.

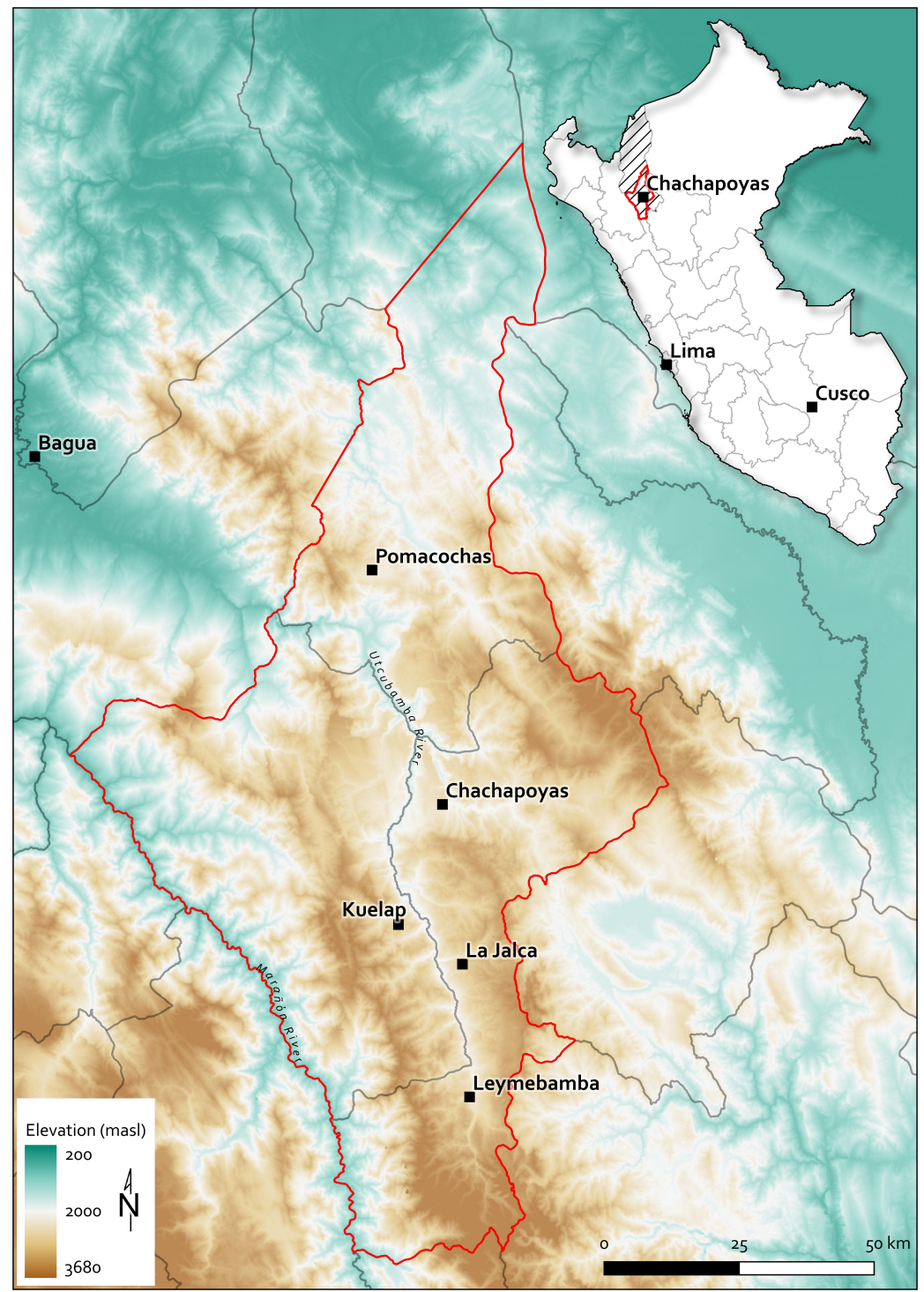

Figure 1. Map showing research area (red polygon) and principal sites. Hashed lines in inset indicate the Department of Amazonas.

In this paper, we present the results of such an analysis. We first present the results of a large-scale "virtual survey" of ancient terraces and settlements in southern Amazonas, conducted using the Geospatial Platform of Andean Culture, History, and Archaeology (GeoPACHA). We employ the resulting data to characterize ancient land-use patterns by analyzing the distribution of ancient terracing with respect to general variables such as elevation, slope, and proximity to modern-day settlements. Second, we investigate where deforestation has occurred between 2001 and 2019, employing Global Forest Change (GFC) data, processed and publicly provided by the Global Land Analysis \& Discovery laboratory at the University of Maryland [42]. We use this remotely sensed evidence of deforestation 
as a proxy for recent trends in land-use change, seeking to understand what areas are targeted in the expansion of agricultural and pastoral production, why they are targeted, and how the forces driving land-use change in the present differ from those in the past, cf. [32,43]. Together, we investigate whether recent expansions of agriculture are associated with areas with relict terracing. Addressing this question allows us then to assess not only how land-use practices in the past compare to those in the present but also how the former may have structured the latter.

\section{Materials and Methods}

\subsection{Research Context}

Our survey area comprises the provinces of Chachapoyas, Luya, and Bongará, which collectively make up most of the southern part of the department of Amazonas, Peru. Measuring 9187 square kilometers, this study region includes a sizeable portion of the so-called Chachapoyas cultural area, a loosely defined geographic region in the northeastern Peruvian Andes in which the only definitive boundary is the Marañón River to its west [44-46]. Human occupation in this region dates back to at least 12,000 years $\mathrm{BP}[44,47]$, and recent excavations suggest that many sites once thought to date to the Late Intermediate Period (ca. AD 1100-1470) have substantially earlier occupations [48-50]. Ethnohistoric sources suggest that Late Intermediate Period populations were not organized into a cohesive polity but rather comprised different segments of a diverse socio-political and ethnic landscape in which communities shared many cultural traditions (and perhaps, languages) [44,45,51-54]. Settlement patterns appear to vary by subregion $[44,55]$, but hilltop and ridge-top sites are common and range in size from fewer than a dozen structures each in the smallest sites to more than 500 in the largest [56]. Structures vary in floor area, height, and masonry, but their forms are generally circular; some are decorated with elaborate friezes containing both geometric and figurative elements [55,57-60]. While hundreds of these sites have been documented through both pedestrian survey and remote sensing, systematic coverage has been hindered by the region's steep terrain, frequent cloud cover, and often dense vegetation. As the number of stratigraphic excavations in the region increases, so too has understanding of regional chronology. However, it remains unclear whether all hilltop sites, and their associated terraced slopes would have been occupied and in use at the same times-and what percentage of them have occupations dating prior to the Late Intermediate Period.

Topography and ecology in the region are similarly diverse. Elevations range from 550 to $4200 \mathrm{~m}$ above sea level (masl) and encompass a wide range of ecosystems and microclimates, from arid canyons to cloud forests and high altitude grasslands. Whereas agriculture in some portions of the central and southern Andes must contend with limited and seasonal rainfall, often by means of complex irrigation networks [4], southern Amazonas is generally quite wet [61]. While rainfall varies based on elevation, season, and microregion, monthly precipitation is generally high enough that agriculture in this region is almost exclusively rainfed. In comparison to some well-documented portions of the Central Andes, such as the Urubamba Valley (Cuzco), the Lake Titicaca Basin, and the Colca Valley (Arequipa), stone-faced terracing is also uncommon in southern Amazonas. Instead, most terraces are earthen and follow mountain contours in the form of large, widely spaced berms [25,61,62]. Though most terraced slopes are found at elevations where maize agriculture is possible, the cultivation of tubers and a diverse range of other crops was likely widespread in the past and remains so today $[25,63]$. Evidence documenting the organization and extent of pastoralism is less clear, but archaeofaunal and isotopic analyses [63,64] as well as ethnohistoric sources [65] (p. 229) suggest that camelids were part of local diets and economies during the Late Intermediate Period as well.

The Inka invasion of the region appears to have occurred in two stages-an initial, largely unsuccessful incursion in the 1450s, followed by a conquest carried out circa AD 1470 [47,51,57,65-67]. Following these campaigns, the region became a provincial constellation within Tawantinsuyu (the Inka empire), referred to as Chachapoyas, from 
one of many ethnic groups living therein. As they did in many other conquered provinces, the Inkas engaged in a widespread campaign of population resettlement in Chachapoyas, removing some residents to serve as mitmaqkuna in state-defined roles (such as soldiers in Inka armies) and moving other communities (including at least one group of ceramic artisans from the more southerly province of Wankas) to the Utcubamba valley [68]. Many sites, particularly those at higher elevations, may have been abandoned at this time, while others show continued occupation, demonstrated in the form of constructions of distinctly Inka structures (e.g., $[56,59,69])$. The invasion of the region by Spanish forces in the 1530's and the establishment of the settlement of San Juan de la Frontera de Los Chachapoyas led to still further disruption, and significant decline in Indigenous populations occurred in the 16th and 17th centuries due to epidemics and colonial violence $[13,51,57]$.

The combined population of Amazonas continued to be quite low during the 18th through mid 20th centuries, and the region remained relatively disconnected from the coastal and highland areas to the west until road construction in the early 20th century [32,70]. More recently, regional population has increased apace with national rates of population growth, rising from 254,560 people in 1981 to 418,365 people in 2017, while national population over the same period has increased from approximately 17 million to 32 million people (inei.gob.pe). Economic growth in Amazonas in the same period has been driven by agriculture and cattle raising as well as tourism amidst widespread economic growth within Peru that saw national GDP per capita increase more than threefold between 2000 and 2019 (worldbank.org, accessed on 10 December 2020). Local road networks have greatly expanded during this period, as municipalities have sought to provide farmers with means of bringing their crops to market more efficiently. It is in the context of these developments that we observe changes in land-use and its expansion into previously forested areas of southern Amazonas.

\subsection{Predictor Variables}

To characterize patterns of land-use and landcover in both the past and present and to explore the forces driving changes in the spatial distribution of agriculture, we employ elevation, slope, and distance to modern-day inhabited places. We selected these three variables due to their inferred relevance for mountain agriculture, both in the past and present, thus allowing us to characterize particular preferences and trends in land-use. Moreover, because we consider these variables to influence land-use patterns in the present, we must account for them in ultimately testing the effects of our fourth predictor variable: the presence or absence of ancient agricultural terraces. That is, by holding the effects of elevation, slope, and distance from modern settlements constant, we can investigate what effect, if any, the presence of ancient agricultural terraces has on the land-use patterns of farmers today.

Elevation and slope have clear relevance for agriculture, both in the past and present, by impacting the kinds of microclimates that crops are exposed to and controlling rates of water flow and soil stability [71]. Both variables also impact other relevant factors for agriculture, such as insolation and aspect, which we do not directly evaluate here [72]. While all these factors can either limit or enhance the suitability of agriculture, they may be mediated in part through the construction of agricultural terraces and other landscape modifications as well as by the selection of particular crops that are better suited for different elevations or watering regimes $[2,10,19,29]$. That is, land-use patterns in the region should not be assumed to be wholly structured by these environmental variables. Perceptions of agricultural suitability may also vary depending on subsistence practices or sociocultural contexts and can themselves be altered through landscape interventions and modifications [73,74]. Given the marked topographic diversity of the region, we expect then that the analysis of elevation and slope should reveal differing and not necessarily overlapping land-use patterns between the past and present. For this study, we employ 90-meter resolution Shuttle Radar Topography Mission (SRTM) digital elevation model (DEM), from which we also derive slope values. 
Proximity to inhabited places, on the other hand, is a more complicated variable, particularly as it relates to ancient land-use patterns. We include it here in recognition of the fact that land-use intensity, in both the past and present, generally decreases with distance away from settlements [21]. Such a relationship can be based on any number of factors, ranging from concerns of safety and defence to high regional settlement density and circumscription to practical limitations of travel and transport. As such, we find little reason to assume that the spatial relationship between settlement and land-use should remain constant through time (though see e.g., [75,76]). Travel and transportation costs can, for example, be greatly reduced by the expansion of road networks and by the adoption of animal or motorized means of conveyance. Moreover, the distribution of inhabited places today is likely a poor approximation of settlements in the past, both in terms of location as well as regional density. Nevertheless, for the sake of holding constant the effect of distance on modern-day land-use patterns, which we then compare to ancient land-use patterns, we employ modern-day settlement locations for analysis of both ancient and modern land-use patterns. We utilize place locations based on OpenStreetMap data, which record 333 unique locations ranging from the provincial capital of Chachapoyas to small villages made up of only a handful of residences [77]. To evaluate distance between modern-day settlement and areas of ancient and modern land-use, we calculated the Euclidean distance between each area and the nearest inhabited place. We then characterized land-use patterns in the past and the present relative to these three variables and compared their distributions using Kolmogorov-Smirnov (K-S) nonparametric tests.

To evaluate the effect of ancient land-use patterns on those of the present, we use general linear regression modeling, with the presence or absence of forest loss as our response variable and the presence or absence of terracing, elevation, slope, and distance to populated settlements as our predictor variables. We employ general linear regression modeling because forest loss is coded here as binary (present or absent) and therefore requires a logit transformation to fit the binomial probability distribution. All analyses presented here were conducted in R [78], with necessary datasets and code scripts made available in the Supplementary Materials.

\subsection{GeoPACHA}

To establish the locations of ancient terraces and to evaluate their relationships with areas of modern forest clearance, we conducted "virtual" archaeological survey using the Geospatial Platform for Andean Culture, History, and Archaeology (GeoPACHA) [79]. GeoPACHA is a browser-based platform designed to facilitate systematic visual survey and analysis of high resolution aerial imagery for archaeological applications. The interface allows users to access high-resolution satellite imagery and elevation layers and provides various tools for tagging and categorizing archaeological "loci" using point themes as well as a structure of tiered access and editing to facilitate the review of the resulting data. Users are organized into "projects" and trained to recognize regionally specific forms of archaeological sites and landscapes in aerial imagery by project leads/regional editors. They then tag and assign attributes to all archaeological sites and features within an assigned series of $2 \times 2 \mathrm{~km}$ grid squares, each further subdivided into $500 \times 500 \mathrm{~m}$ octants to allow users to keep track of survey coverage. Following completion of a survey grid square, regional editors review all of the loci and attribute data submitted within their research teams; these data are reviewed a second time by the project's general editors (Wernke and VanValkenburgh).

Using GeoPACHA, our team for this project spent two months digitally surveying the region and tagging areas with evident terracing. Due to the high density of terraces in many parts of the region and the challenges of parsing continuous landscape features into discrete loci, the team effectively sampled terracing at a $500 \mathrm{~m}$ interval, placing one locus within each $500 \times 500 \mathrm{~m}$ grid square within which terracing (or other extensive landscape features of interest, such as canals) was present. Rather than surveying the entirety of southern Amazonas, we sampled the project area in east-west swaths of grid 
squares, from the Marañon River in the west to the border of the province of Rodríguez de Mendoza in the east. We planned these survey swaths such that they would cover the greatest range of possible topographic and environmental conditions, from deep river valleys to high mountain peaks. Surveyors scanned in parallel tracts, with each survey swatch separated by at most $4 \mathrm{~km}$ (Figure 2). In this way, we surveyed 13,440 $500 \times 500 \mathrm{~m}$ grids, representing $3360 \mathrm{sq} \mathrm{km}$, or about a third of our survey region. For each terrace location, we extracted elevation and slope values and calculated the Euclidean distance to the nearest modern-day settlement.
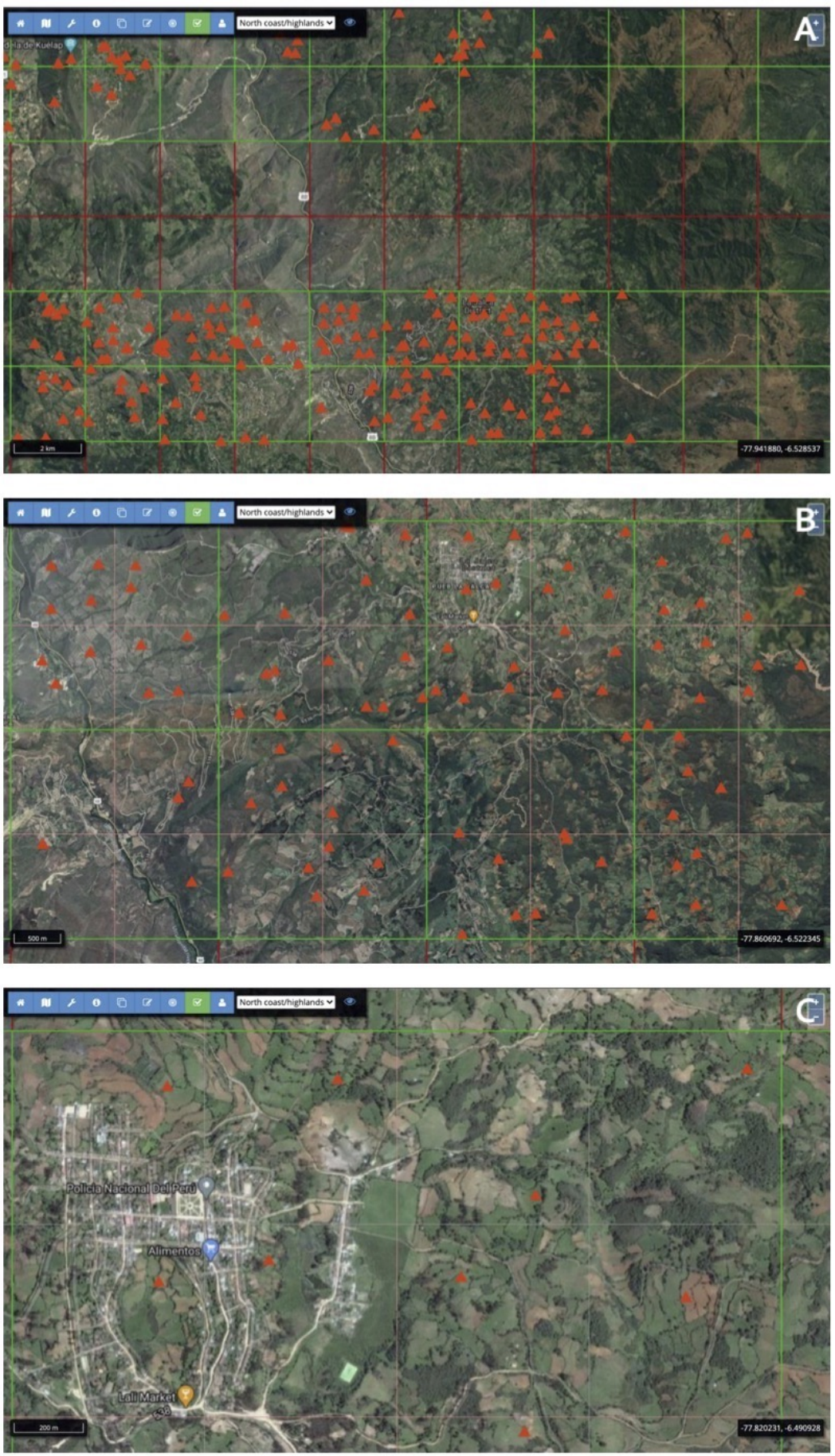

Figure 2. Multiscalar views of GEOPACHA interface showing parallel survey swaths (A), individual tracts $(\mathbf{B})$, and individual $2 \times 2 \mathrm{~km}^{2}$ grids $(\mathbf{C})$. Green squares indicate surveyed grids, while red triangles indicate ancient terrace and site locations. 
Though we cannot determine precise chronological information for terraces based solely on satellite imagery, even where obvious morphological differences exist [25,61,62], we assume that all terraces were built, at the latest, before approximately AD 1600 . We make this assumption based on the aforementioned severity of population decline and land abandonment taking place after Spanish invasion across the Andes, making it unlikely that many new terraces were constructed over the past several centuries. We also draw on the large body of terrace studies from the Andes that focus on rehabilitating and expanding ancient agricultural terraces for the purposes of agricultural production and erosion mitigation today $[18,23,39,80-82]$. Though these studies highlight cases where terraces have been successfully (re)implemented by local communities, even those cases demonstrate the significant obstacles and challenges disincentivizing terrace use today for many communities across the Andes [29]. As in other regions, relict agricultural terraces in our study region have been and continue to be degraded and destroyed by contemporary farming practices [25] (p. 199), which is supported by our own anecdotal experience working in the region. Thus, even in cases where agricultural terraces are in use today, we assume that their initial dates of construction are prior to the seventeenth century AD.

\subsection{Forest Loss Data}

To investigate recent histories of land-use, we rely on Global Forest Change (GFC) data processed and publicly provided by the Global Land Analysis \& Discovery laboratory at the University of Maryland [42]. Derived from $30 \mathrm{~m}$ resolution Landsat data, the most recent available version of GFC data cover the period from 2001-2019 and include layers pertaining to tree canopy cover, forest gain, and forest loss. Forest loss is defined as "a stand-replacement disturbance or a change from a forest to non-forest state" and is coded with values between 0 and 19, where 0 corresponds to no detected forest loss and 1-19 corresponds to the year in which forest loss was first detected [42] (p. 850). Thus, for example, a cell coded as 5 indicates that forest loss was detected within the area of that cell in 2005. These classifications are made based on time-series spectral metrics, training data, and hierarchical decision trees. Elsewhere, GFC data have been successfully employed for a wide range of scientific and public policy applications (e.g., [83-85]), including most notably the Global Forest Watch platform [86].

For this study, we employ the forest loss layer of the GFC datasets (Figure 3). We began by masking out the extent of our survey area and by calculating initial summary statistics to characterize general trends in forest loss over the past two decades in this region. We then proceeded to vectorize the data, aggregating congruent cells with identical values such that an area made up of multiple cells where forest loss was detected in a certain year was returned as a single polygon. We refer hereafter to such areas as Contiguous Forest Loss Areas (CFLAs; $n=77,745$ ), which we employ as our initial units of analysis and for which we report additional summary statistics. These polygons are deemed to represent single episodes of forest loss, as distinguished from forest loss that may occur immediately adjacent to them in different years.

We subset this dataset according to procedures outlined in the Supplementary Materials, resulting in a final CFLA dataset of 1506 polygons that we employ for further analysis. Additionally, another dataset of 1506 polygons was generated within the parts of the forest loss layer that were coded as not having any forest loss. These polygons (No Forest Loss Area, NFLA) measured $7385 \mathrm{sq} \mathrm{m}$ in area, which is the average area of the CFLAs in our final dataset. For each CFLA and NFLA, team members used available Google and Bing imagery, including Google Earth Pro's historical imagery tool, to code each polygon for whether it contained agricultural terracing. In cases where imagery was unavailable or insufficient (see below) or where vegetation regrowth limited adequate visibility of the ground surface, those polygons were coded as indeterminate. Once coded, all individual datasets were joined back together. We then converted these polygons to points, based on their centroids; extracted mean elevation and slope values from our $90 \mathrm{~m}$ 
SRTM DEM; and calculated the Euclidean distance from each CFLA and NFLA to the nearest populated place.

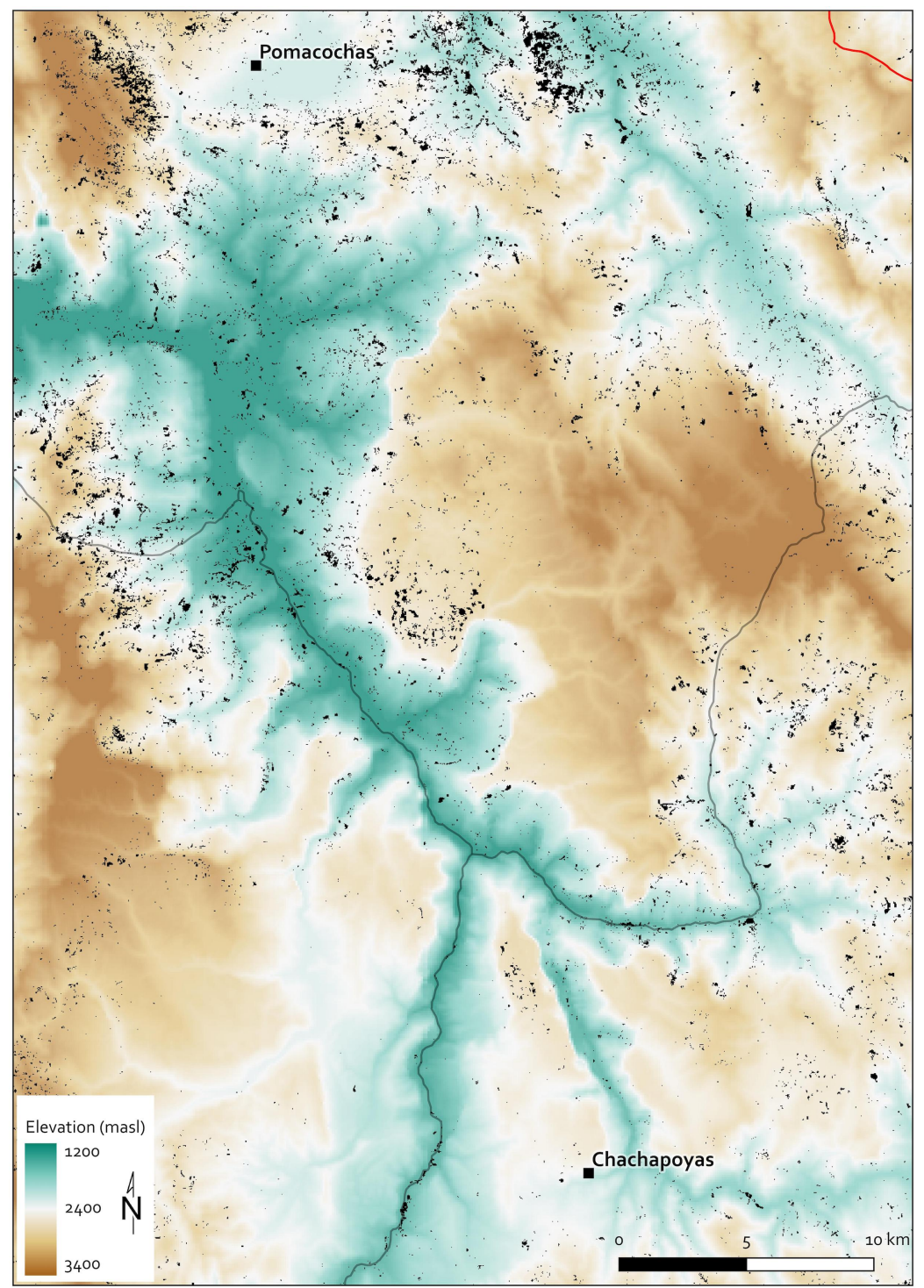

Figure 3. View of the study region showing areas of forest loss (black).

\subsection{Methodological Considerations}

In conducting these analyses, we acknowledge several limitations, some of which are particular to our survey area. First, this region is characterized by high annual precipitation, steep and rugged terrain, and vast areas of still forested land. Moreover, frequent cloud cover limits the number of usable observations that satellites are able to make, creating frequent spatial and temporal gaps in available imagery. The result is large areas within our survey region for which imagery is either unavailable or of such low resolution that it is not possible to identify terraces within it. As discussed in the Supplementary Materials, these limitations led us to exclude years after 2016 from our analysis due to the absence of high resolution commercial imagery, despite forest loss data being available.

Second, regarding our use of forest loss data, we must contend with the fact that areas coded as lacking in forest loss were in many cases themselves deforested prior to 2001, when our forest loss data begins. It is thus more accurate to describe our general linear regression model as modeling the relationship between our predictor variables and the presence or absence of forest loss in the past 20 years. An additional limitation of the forest loss data is that, by its very nature, it cannot be used to assess land-use changes in areas 
lacking in forests. For our study region, such areas are generally found above $3500 \mathrm{~m}$ in elevation, though this treeline varies across the landscape and is, in part, the result of anthropogenic processes $[57,87,88]$ (pp. 22-23). However, agricultural terraces are found in many places above this elevation, particularly around ridgetop sites that can be as high as 4200 masl [2,28]. The exclusion of these areas from the forest loss data, which we use as a proxy for modern-day land-use is therefore problematic. We can reasonably resolve this issue; however, since use of these areas for subsistence today is limited and almost exclusively limited to pasturage, with land modification largely restricted to intentional burning events that land owners claim encourage the growth of highland grasses, we adopt $3500 \mathrm{~m}$ as a rough upper limit for modern-day agricultural land-use when comparing ancient to modern land-use strategies.

Third, substantial parts of this region remain heavily forested, with limited LiDAR applications to-date [89]. As a result, we cannot know the actual distribution of agricultural terraces within the region nor how representative our dataset of remotely sensed terraces is. Many areas that are coded as not having forest loss may indeed have terraces, which we simply cannot identify due to the lack of regional airborne LiDAR data. In the same vein, it is certain that ancient communities in this region practiced a wide assortment of land-use strategies aside from terraced agriculture. Valley bottom cultivation, pastoralism, horticulture, and other such strategies would have been essential elements of local subsistence strategies [63] but would not have left as enduring or visible landscape modifications as the agricultural terraces studied here. Our characterization of ancient land-use is therefore limited only to terraced land-use and to those environments where ground cover is visible.

\section{Results}

\subsection{Where Are Ancient Terraces Located?}

The results of our survey with GeoPACHA resulted in the identification of 2968 $500 \times 500 \mathrm{~m}$ grids with terraces located within them, representing $22 \%$ of our surveyed area. Within the survey area, we identified terraces in every west-east transect. Gaps in our survey swaths where no terraces were located were most frequently attributed to either declines in visibility due to forest vegetation or imagery resolution, or to topographic extremes such as the Marañon and Utcubamba river ravines or the highest elevation areas of our study region. With respect to these topographic conditions, the mean elevation of terrace locations was 2684 masl, with a standard deviation of $408 \mathrm{~m}$. The distribution of values, according to a Shapiro-Wilk's test, was non-normal ( $\mathrm{W}=0.99, p<0.01)$, with two evident modes around the mean and a third, less pronounced, mode at around 3500 masl (Figure 4). The mean slope at which terraces are found was 17 degrees, with a standard deviation of 7 degrees, while the mean Euclidean distance of terraces from modern-day inhabited places was $2332 \mathrm{~m}$, with a standard deviation of $1637 \mathrm{~m}$. Both slope $(\mathrm{W}=0.98$, $p<0.01)$ and distance $(W=0.99, p<0.01)$ also had non-normal distributions.
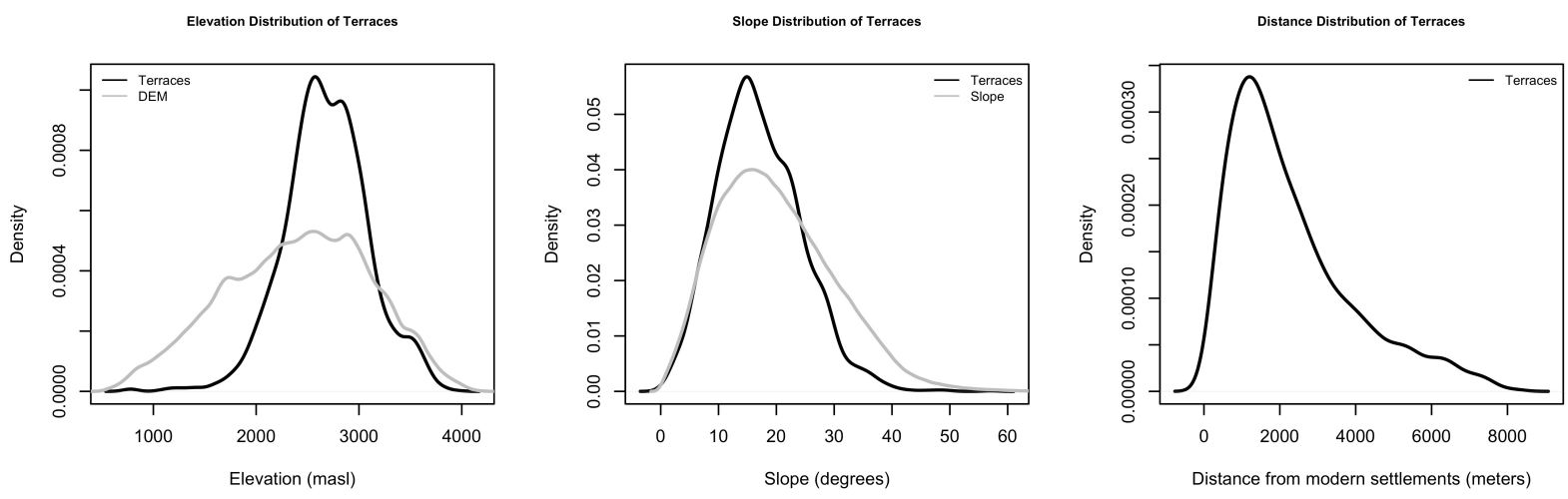

Figure 4. Density distribution plots showing elevation, slope, and distance values for ancient terraces. 


\subsection{Where Is Land-Use Taking Place Today?}

Within our survey area, the total amount of forest loss measured between 2001 and 2019 was $221 \mathrm{sq} \mathrm{km}$, or about $2 \%$ of our survey region's total area. The yearly average was approximately $11.63 \mathrm{sq} \mathrm{km}$, though this loss was neither consistent nor linear through time (Figure 5A). Rather, forest loss seems to fluctuate over two or three year cycles, creating a jagged pattern through time that may be the result of interannual variability in rainfall or market prices for agropastoral products. We note, for example, the occurrence of several droughts in the region, most notably in 2005, 2007, and 2010, which have had enduring effects on the region's vegetation $[90,91]$. Having vectorized the forest loss data and aggregated congruent cells of identical values, we obtain a dataset of 77,745 CFLAs, with an average area of $2834 \mathrm{sq} \mathrm{m}$. The average area of CFLAs per year is also variable, holding relatively steady around the overall average for the first decade of our study range and then fluctuating widely over the next decade (Figure 5B). In other words, the size of individual deforestation events has since 2014 become more variable and, in some years, much larger. As of 2019, for example, the average area of CFLAs had risen up to $3737 \mathrm{sq} \mathrm{m}$, from an average area of $2923 \mathrm{sq} \mathrm{m}$ in 2001.
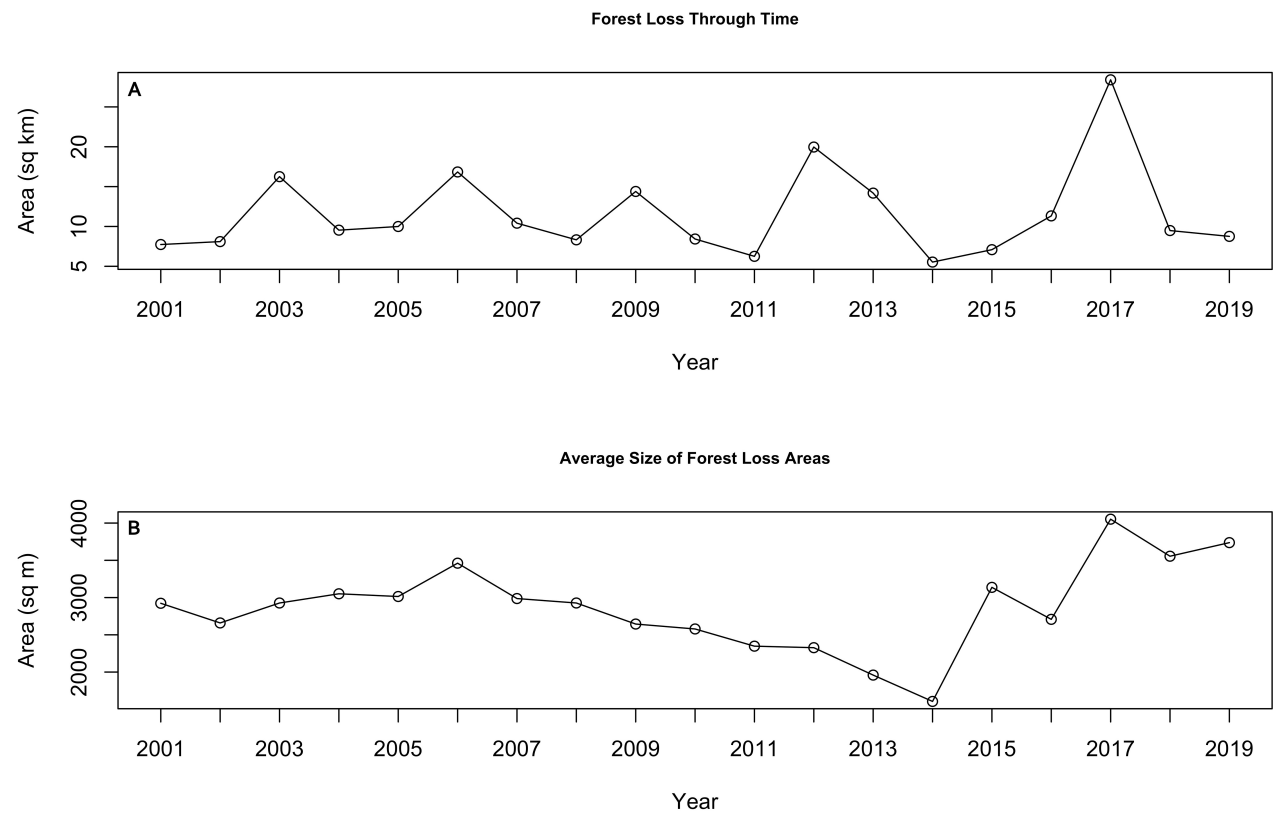

Figure 5. Areal forest loss through time (A) and average size of forest loss areas per year through time (B).

Investigating these inter-annual trends further in relation to elevation, slope, and distance (Figure 6), we find that there is a clear negative trend in the elevation of forest loss, indicating that deforestation has been occurring at progressively lower elevations from 2001-2019. Within this period, the mean elevation of forest loss was about 2319 masl, with a standard deviation of $526 \mathrm{~m}$. No apparent trend was observed for the slope at which deforestation was taking place, with the mean slope of forest loss being 19 degrees, with a standard deviation of 9 degrees. A positive trend was observed for distance, indicating that the distance from modern settlements at which deforestation was taking place has generally increased through time. The mean Euclidean distance to modern-day inhabited places is $3613 \mathrm{~m}$, with a standard deviation of $3835 \mathrm{~m}$.

We also investigated the forest gain data layer provided by Global Land Analysis \& Discovery to evaluate whether forest loss trends were at all reversed by subsequent reforestation. We found, however, that forest gain in our study region for the period of 2001-2019 amounted to only $10.2 \mathrm{sq} \mathrm{km}$ in total, or less than $5 \%$ of the total forest 
loss during that same period. Reforestation has therefore had a minimal effect on net deforestation trends.
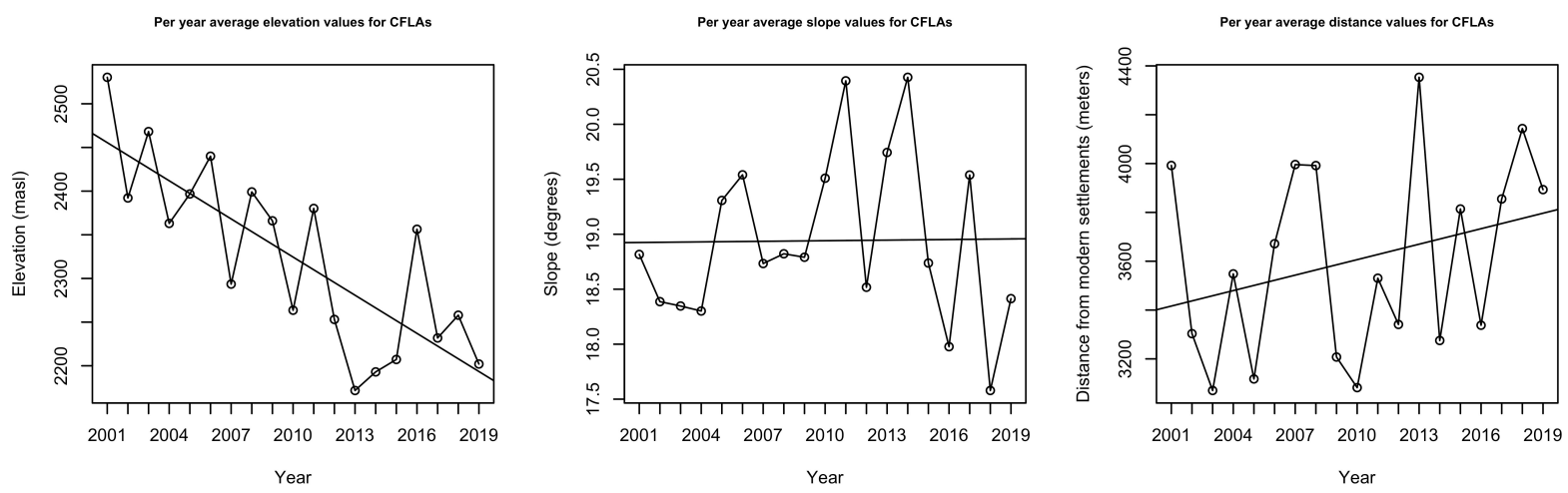

Figure 6. Average elevation, slope, and distance values for CFLAs through time.

\subsection{What Effects Does Ancient Land-Use Have on Modern Land-Use?}

Comparing the distributions of these environmental variables between ancient terraces and modern-day forest loss, we find that ancient terraces are found, on average, $340 \mathrm{~m}$ higher in elevation than modern-day forest loss. Visual inspection of these density distributions shows that while they are overlapping, ancient terrace elevation values have a more restricted distribution than that of forest loss (Figure 7). We determine that these distributions are statistically different through a K-S test $(\mathrm{D}=0.34, p<0.01)$. Likewise, for slope, we find that ancient terraces are on average found on slopes about 2 degrees less steep than where modern-day forest loss is taking place. Though these distributions are far more overlapping than elevation, we find that they are nevertheless statistically distinct $(\mathrm{D}=0.10, p<0.01)$. Finally, for distance, we find that ancient terraces are $1189 \mathrm{~m}$ closer to modern-day settlements than areas of modern-day forest loss. These distributions are also statistically different $(\mathrm{D}=0.17, p<0.01)$.
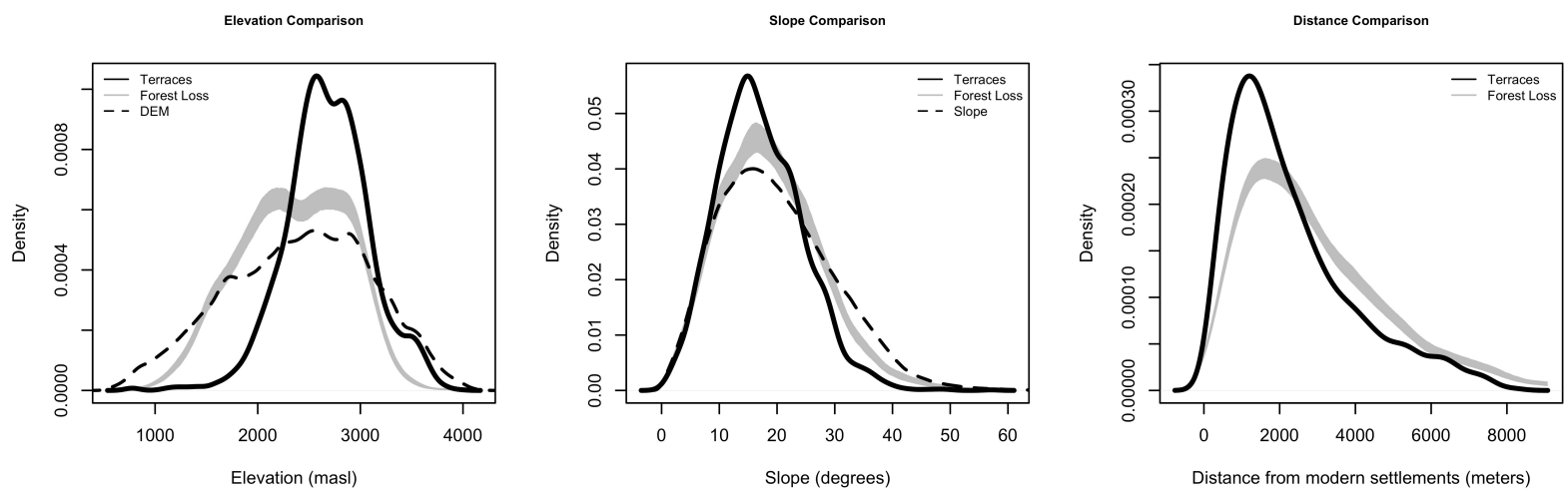

Figure 7. Comparison of density distributions of ancient terraces and modern forest loss areas.

Looking more closely at the effect of ancient terracing on modern-day forest loss, based on our investigation of terrace locations within sampled CLFAs and NFLAs, we fit a binomial general linear regression model to our data to test how well the presence or absence of terraces, elevation, slope, and distance from settlements can predict the occurrence of forest loss. Using ANOVA likelihood ratio tests, we find that the presence or absence of terraces, elevation, and slope all have statistically significant impacts on the probability an area will experience forest loss. The inclusion of distance as a predictor variable did not significantly improve the model.

Plotting the effects of terrace presence on predicted forest loss, while holding the others constant, we can see that the presence of terracing does increase the likelihood of 
forest loss taking place (Figure 8). While these results indicate some kind of relationship between ancient and modern-day land-use, the overall explanatory power of the model is ultimately quite low $\left(D^{2}=0.06\right)$. In other words, the presence or absence of ancient terraces, while accounting for elevation, slope, and distance, can only predict about $6 \%$ of the total forest loss. We can therefore say that, while the presence of ancient terraces does have a significant impact on whether forest loss takes place, very little of the overall amount of deforestation can actually be predicted based solely on the presence or absence of terraces. The high amount of unexplained variance suggests that it is likely that there are additional variables worth including in our model.

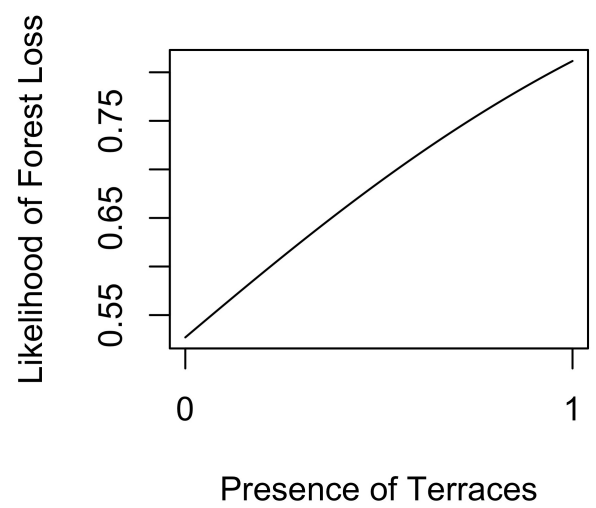

Figure 8. Effect of terracing on likelihood that forest loss takes place.

\section{Discussion and Conclusions}

Long-term and regional-scale studies of land-use histories are valuable because they can reveal general trends that are often difficult to determine from studies of particular periods or sites. These trends can show profound changes, reflecting perhaps a marked transition in subsistence practices or settlement organizations, or alternatively little change at all, reflecting long-term stability and continuity in land-use practices. Changes in landuse may occur gradually, with incremental transitions over many centuries, or suddenly all at once, perhaps in the context of a catastrophic event. However they occur, studying long-term histories of land-use in the context of environmental, sociopolitical, economic, and technological developments permits the investigation of the shifting motivations, constraints, and opportunities that local communities experienced through time. Such regional-scale generalizations may obscure local nuances, precisely those that site-specific studies would help identify but nevertheless provide a useful model for defining macroscale trends. These models can also themselves help identify those local outliers and evaluate the influences of certain variables on the overall pattern. Together, the combined use of regional and site-specific studies can provide new insights into long-term histories of land-use and landscape development over time.

Our study of the southern Amazonas region has thus sought to characterize the pattern of land-use taking place in the past, as indexed by the presence of agricultural terraces, and compare it to that taking place today, as indexed by evidence of deforestation. Relative to elevation, we find that ancient terracing exhibits a multi-modal distribution, suggesting either contemporaneous use of several elevation ranges or instead the use of these different zones during different periods. If representing different periods, it is possible that one of the higher of the modes represents an LIP settlement pattern common in other parts of the Andes, when settlement moved to mountain tops and prioritized cultivation of otherwise marginal slopes due to concerns for safety and the frequent risk of warfare [58]. Our ability to test these scenarios is limited by the temporal resolution of our terrace dataset, but we can nevertheless conclude that, of the elevation areas available to them, the pre-Columbian communities of the region preferentially exploited relatively high elevation areas. This pattern fits with previous appraisals of settlement and land-use in the region [44]. 
However, what this multi-modal distribution also shows is that there is no necessarily optimal elevation for terraced agriculture. We find terraces in our study region over a range of some 1500 masl and well above the 3200 masl limit frequently cited for maize agriculture. Such a broad range of elevation values demonstrates that other factors can influence the suitability of terracing, such as the kinds of crops grown, agricultural technology (such as footplow vs. oxen-drawn plow), integration with other subsistence regimes such as pastoralism, and settlement and population density. Likewise, our consideration of slope shows that the steepest slopes of the region are not actually those that are most frequently terraced, as one might suspect. Indeed, terraced areas are, on average, found on less steep slopes than modern-day areas of deforestation, though the difference is small (two degrees). This pattern challenges the common conception that terracing is necessarily an adaptation to steep slopes, which require terraces to be cultivated. Our results show that land-use in the present often takes place on slopes of greater than 20 degrees, without terracing.

Areas of ancient terracing are also, on average, closer to modern-day settlements than areas of contemporary forest loss. This pattern is, at first impression, somewhat counterintuitive. While modern-day settlements may have some overlap with areas of ancient settlement (e.g., La Jalca [62]), the overall pattern of resettlement to lower elevations, begun by the Inka, should result in areas of ancient land-use being further from modernday settlements, rather than closer. We interpret this result as reflecting the fact that ancient and modern-day settlements are likely separated more by elevation than actual linear distance. Moreover, the ever expanding network of roads being built today throughout southern Amazonas means that farmers can exploit much further afield in areas that may not have been actively settled in the past. Though we do not include roads in this study as a predictor variable, due to difficulties of associating individual road segments with their years of construction, previous work has consistently shown the highly influential role that roads play in directing rates and locations of deforestation in other parts of the Amazon [43,92-94]. It is thus likely that similar effects are present in this region as well, as seen in the trend of deforestation towards greater distances from settlement. We interpret this pattern as indicating that roads are today providing the means for people to expand their land-use at progressively greater distances from their homes (Figure 8). In Figure 8, we also note the trend of deforestation towards lower elevations and therefore away from areas where ancient terracing is most frequent. The fact that areas further away from settlements are being prioritized over these higher elevation areas indicates that there are some factors (such as the ever expanding road network) that make farming at higher elevations less attractive than farming at greater distances away.

It is these kinds of factors that may explain the overall poor predictive power of ancient terraces on modern-day deforestation in our model, and there are also likely other variables at work that we have not sufficiently modeled. We have, for example, operated under the assumption that all instances of forest loss sampled here are the result of forest clearance for the purpose of agropastoral production $[95,96]$. Though we have not quantified what proportion of forest loss is indeed due to clearance for subsistence practices, it is demonstrably true that some percentage of forest loss detected by Global Land Analysis \& Discovery within our survey region is the result of mining, road construction, landslides, and other non-agropastoral processes. There is therefore little reason to expect areas of ancient terracing to have bearing on where these other non-agropastoral processes are taking place, which likely contributes in part to the high variance in forest loss that remains unexplained by our model.

However, even if we assume that all instances of modern-day forest loss are actually related to agropastoral production and our model does in fact only explain about $6 \%$ of its variation, such a result is still not necessarily surprising. The minimal influence of ancient terracing on ongoing processes of land development and agropastoral expansion today, even when accounting for the methodological considerations reviewed above, can be explained, at least in part, by the fact that farmers today are likely to have different requirements and preferences than farmers in the past (as seen by a shift towards lower 
elevations). While research has indeed shown that areas with pre-existing agricultural terracing have higher rates of soil nutrients, soil depth, and better drainage [10,34] and while our own conversations with farmers in the region indicates that they are aware of these benefits, the fact remains that ancient terraces are not being actively maintained and preserved. In many cases, they are progressively being weakened and destroyed through oxen-driven plowing [97], and the long-term benefits of terraced agriculture are often offset by the high labor and capital costs of such improvements [81].

What this study has shown, therefore, is that terracing is not only environmentally driven nor determined but also arises from particular historical and sociocultural contexts. While the overlaps between areas of ancient and modern-day land-use are evident, both from our analysis here and from more casual observations on-the-ground, we should not necessarily assume that these overlaps confirm the innate benefits of ancient land-use practices. We certainly do not dispute the benefits that terracing can provide or the ability of these forms of landesque capital to retain those benefits into periods long after their initial periods of construction, but we caution against the assumption that well-adapted land-use practices of the past must be similarly appropriate for the present. As discussed, farmers in the region are often well-aware of the benefits of terracing and eager to employ them under the right circumstances [98]. It is possible that this is reflected in the statistically significant relationship between ancient terracing and forest loss. However, we should also be mindful of what those circumstances are, particularly when they arise from historical legacies of colonialism and the modern-day effects of global market capitalism $[27,99,100]$.

We conclude therefore with a call for continued investigation of land-use practices in the past and present at regional scales, which together with site-based studies can provide essential information about long-term environmental and social changes. Particularly in the case of landscape modifications such as agricultural terraces, which are frequently expansive in their extent and multi-temporal in the duration of their use, regional models can help distinguish general trends from local variations. In doing so, we can gain a better understanding of how and why local communities through time have modified, expanded, or abandoned anthropogenic landscapes to suit their contemporary needs. Such knowledge is critical for evaluating the relevance and role that ancient land-use practices may have for confronting the challenges of the present.

Supplementary Materials: The following are available online at https:/ / osf.io/p24xh/ and https: / / www.mdpi.com/article/10.3390/rs13122274/s1, SupplementaryMaterials.pdf: an RMarkdown file containing all code and associated files necessary to replicate this study. terrace_pit.zip: A shapefile containing the point vector file recording terrace locations collected through GEOPACHA. sample_poly.zip: A shapefile containing the polygon vector file recording sampled forest loss areas and whether or not they contain terraces. nl_poly.zip: A shapefile containing a polygon vector file pertaining to areas without forest loss.

Author Contributions: Conceptualization, D.P. and P.V.; methodology, D.P.; validation, D.P., P.V., P.A., A.C., J.H., A.J.R.D., and B.S.; formal analysis, D.P.; data curation, P.V. and S.W.; writing-original draft preparation, D.P., P.V., and S.W.; funding acquisition, P.V. and S.W. All authors have read and agreed to the published version of the manuscript.

Funding: Funding for the development of GeoPACHA was provided by a Digital Extension Grant from the American Council of Learned Societies to Steven Wernke and Parker VanValkenburgh as well as by a Spatial Archaeometry Research Collaborations grant from the University of Arkansas. Partial funding to support the collection of virtual survey data was provided by the SPRINT program at Brown University.

Data Availability Statement: The data presented in this study are openly available in Open Science Framework at https://osf.io/p24xh/ (accessed on 10 December 2020). These data include an RMarkdown file containing all code and associated files necessary to replicate this study.

Acknowledgments: We thank Alex Drakos and John Wilson for the development of GeoPACHA and Michael Palace, Mark Bush, and Fausto Sarmiento for their helpful feedback and discussion. 
We also thank the three anonymous reviewers for their constructive feedback and the editors of this Special Issue for their invitation.

Conflicts of Interest: The authors declare no conflicts of interest.

\section{References}

1. Brooks, S.O. Prehistoric Agricultural Terraces in the Rio Japo Basin, Colca Valley, Peru. Ph.D. Thesis, University of WisconsinMadison, Madison, WI, USA, 1998.

2. Denevan, W.M. Cultivated Landscapes of Native Amazonia and the Andes; Oxford University Press: Oxford, UK, 2001.

3. Donkin, R.A. Agricultural Terracing in the Aboriginal New World; University of Arizona Press: Tucson, AZ, USA, 1979.

4. Guillet, D. Terracing and Irrigation in the Peruvian Highlands. Curr. Anthropol. 1987, 28, 409-430. [CrossRef]

5. Langlie, B.S. Building ecological resistance: Late intermediate period farming in the south-central highland Andes (CE 1100-1450). J. Anthropol. Archaeol. 2018, 52, 167-179. [CrossRef]

6. Treacy, J.M. Las Chacras de Coporaque: Andeneria y Riego en el Valle del Colca; Instituto de Estudios Peruanos: Lima, Peru, 1994.

7. Branch, N.P.; Kemp, R.A.; Silva, B.; Meddens, F.M.; Williams, A.; Kendall, A.; Pomacanchari, C.V. Testing the sustainability and sensitivity to climatic change of terrace agricultural systems in the Peruvian Andes: A pilot study. J. Archaeol. Sci. 2007, 34, 1-9. [CrossRef]

8. Doolittle, W. Agricultural Changes as an Incremental Process. Ann. Assoc. Am. Geogr. 1984, 74, 124-137. [CrossRef]

9. Kemp, R.; Branch, N.; Silva, B.; Meddens, F.; Williams, A.; Kendall, A.; Vivanco, C. Pedosedimentary, cultural and environmental significance of paleosols within pre-hispanic agricultural terraces in the southern Peruvian Andes. Quat. Int. 2006, 158, 13-22. [CrossRef]

10. Nanavati, W.P.; French, C.; Lane, K.; Oros, O.H.; Beresford-Jones, D. Testing soil fertility of Prehispanic terraces at Viejo Sangayaico in the upper Ica catchment of south-central highland Peru. Catena 2016, 142, 139-152. [CrossRef]

11. Kosiba, S. Cultivating Empire: Inca intensive agricultural strategies. In The Oxford Handbook of the Incas; Alconini, S., Covey, A., Eds.; University Press: Oxford, UK, 2018; pp. 227-246. [CrossRef]

12. McEwan, G.F.; Williams, P.R. The Wari Built Environment: Landscape and Architecture of Empire. In Wari: Lords of the Ancient Andes; Bergh, S., Ed.; Cleveland Museum of Art: Cleveland, OH, USA, 2012; pp. 65-81.

13. Cook, N.D. Demographic Collapse, Indian Peru, 1520-1620; Cambridge University Press: Cambridge, UK, 1981.

14. Murphy, M.S. Colonial Demography and Bioarchaeology. In The Oxford Handbook of the Incas; Alconini, S., Covey, A., Eds.; Oxford University Press: Oxford, UK, 2018; pp. 721-740. [CrossRef]

15. Denevan, W.M. Terrace abandonment in the Colca Valley, Peru. In Pre-Hispanic Agricultural Fields in the Andean Region; Denevan, W.M., Mathewson, K., Knapp, G.W., Eds.; British Archaeological Reports: Oxford, UK, 1987; pp. 1-43.

16. Gade, D.W.; Escobar, M. Village Settlement and the Colonial Legacy in Southern Peru. Am. Geogr. Soc. 1982, 72, 430-449. [CrossRef]

17. Guillet, D. Agricultural intensification and deintensification in Lari, Colca Valley, Southern Peru. Res. Econ. Anthropol. 1987, 8, 201-224.

18. Kendall, A.; Rodríguez, A. Desarrollo y Perspectivas de los Sistemas de Andenerías en los Andes Centrales del Perú; Institut Français d'Études Andines, Centro de Estudios Regionales Andinos Bartolomé de Las Casas: Cuzco, Peru, 2009.

19. Kosiba, S.; Hunter, R.A. Fields of conflict: A political ecology approach to land and social transformation in the colonial Andes (Cuzco, Peru). J. Archaeol. Sci. 2017, 84, 40-53. [CrossRef]

20. Schjellerup, I. Landscape Change and Agricultural Terraces in the Peruvian Andes. In Agricultural and Pastoral Landscapes in Pre-industrial Society: Choices, Stability, and Change; Retamero, F., Schjellerup, I., Davies, A., Eds.; Oxbow: Oxford, UK, 2014; pp. 187-200.

21. Wernke, S.A. A Reduced Landscape: Toward a Multi-Causal Understanding of Historic Period Agricultural Deintensification in Highland Peru. J. Lat. Am. Geogr. 2010, 9, 51-83. [CrossRef]

22. Kendall, A.; Drew, D. The Rehabilitation of Pre-Hispanic Agricultural Infrastructure to Support Rural Development in the Peruvian Andes. In The Oxford Handbook of Historical Ecology and Applied Archaeology; Isendahl, C., Stump, D., Eds.; Oxford University Press: Oxford, UK, 2019; pp. 421-440. [CrossRef]

23. Treacy, J.M. Agricultural Terraces in Peru's Colca Valley: Promises and Problems of an Ancient Technology. In Fragile Lands of Latin America: Strategies for Sustainable Development; Browder, J., Ed.; Westview Press: Boulder, CO, USA, 1989; pp. $209-229$.

24. Fonseca, C. Destrucción de andenes en las comunidades de la cuenca del río Cañete. In Andenes y Camellones en el Perú Andino: Historia, Presente y Futuro; de la Torre, C., Burga, M., Eds.; Consejo Nacional de Ciencia y Tecnología (CONCYTEC): Lima, Peru, 1986; pp. 361-368.

25. Schjellerup, I. Observations on ridged fields and terracing systems in the northern highlands of Peru. Tools Tillage 1985, 5, $100-121$.

26. Treacy, J.M. Building and rebuilding agricultural terraces in the Colca Valley of Peru. Yearb. Conf. Lat. Am. Geogr. 1987, 13, 51-57.

27. Arce, A.; de Haan, S.; Juarez, H.; Burra, D.D.; Plasencia, F.; Ccanto, R.; Polreich, S.; Scurrah, M. The spatial-temporal dynamics of potato agrobiodiversity in the highlands of central Peru: A case study of smallholder management across farming landscapes. Land 2019, 8, 169. [CrossRef]

28. Guillet, D. Land Tenure, Ecological Zone, and Agricultural Regime in the Central Andes. Am. Anthropol. 1981, 8, 139-156. [CrossRef] 
29. Posthumus, H.; De Graaff, J. Cost-benefit analysis of bench terraces, a case study in Peru. Land Degrad. Dev. 2005, 16, 1-11. [CrossRef]

30. Wiegers, E.S.; Hijmans, R.J.; Hervé, D.; Fresco, L.O. Land Use Intensification and Disintensification in the Upper Cañete Valley, Peru. Hum. Ecol. 1999, 27, 319-339. [CrossRef]

31. Sluyter, A. Colonialism and landscape: postcolonial theory and applications; Rowman \& Littlefield Publishers: London, UK, 2002.

32. Schjellerup, I.; Sørensen, M.K.; Espinoza, C.; Quipuscoa, V.; Peña, V. Los Valles Olvidados: Pasado y Presente en la Utilización de Recursos en la Ceja de Selva, Perú; The National Museum of Denmark: Copenhagen, Denmark, 2003.

33. Goodman-Elgar, M. Evaluating soil resilience in long-term cultivation: a study of pre-Columbian terraces from the Paca Valley, Peru. J. Archaeol. Sci. 2008, 35, 3072-3086. [CrossRef]

34. Sandor, J.A.; Eash, N.S. Significance of Ancient Agricultural Soils for Long-Term Agronomic Studies and Sustainable Agriculture Research. Agron. J. 1991, 83, 29-37. [CrossRef]

35. Sandor, J.A.; Huckleberry, G.; Hayashida, F.M.; Parcero-Oubiña, C.; Salazar, D.; Troncoso, A.; Ferro-Vázquez, C. Soils in ancient irrigated agricultural terraces in the Atacama Desert, Chile. Geoarchaeology 2021, 1-24. [CrossRef]

36. Chávez, S.J. Agricultural Terraces as Monumental Architecture in the Titicaca Basin. In Early New World Monumentality; Burger, R.L., Rosenswig, R.M., Eds.; University of Florida Press: Gainesville, FL, USA, 2012; pp. 431-453.

37. Keeley, H.C.M.; Meddens, F.M. Prehispanic agricultural terrace systems in the Chicha-Soras Valley, Peru. Inst. Archaeol. Bull. 1992, 29, 121-138.

38. Gonzales de Olarte, E.; Trivelli, C. ¿Es la recuperación de andenes una vía sustentable para el desarrollo rural? In Conservación y Abandono de Andenes; Llerena, C.A., Inbar, M., Benavides, M., Eds.; Universidad Nacional Agraria La Molina, Universidad de Haifa: Lima, Peru, 2004; pp. 70-78.

39. Camara, L.; Bueno de Mesquita, M. Terraced Landscapes in Perù: Terraces and Social Water Management. In World Terraced Landscapes: History, Environment, Quality of Life; Varotto, M., Bonardi, L., Tarolli, P., Eds.; Springer: Cham, Switzerland, 2019; pp. 119-138.

40. Erickson, C.L.; Candler, K.L. Raised Fields and Sustainable Agriculture in the Lake Titicaca Basin of Peru. In Fragile Lands of Latin America: Strategies for Sustainable Development; Browder, J.O., Ed.; Westview Press: Boulder, CO, USA, 1989; pp. $230-248$.

41. Zimmerer, K.S. Changing fortunes: Biodiversity and peasant livelihood in the Peruvian Andes; University of California Press: Berkeley, CA, USA, 1996.

42. Hansen, M.C.; Potapov, P.V.; Moore, R.; Hancher, M.; Turubanova, S.A.; Tyukavina, A.; Thau, D.; Stehman, S.V.; Goetz, S.J.; Loveland, T.R.; et al. High-Resolution Global Maps of 21st-Century Forest Cover Change. Science 2013, 342, 850-853. [CrossRef]

43. Schjellerup, I.; Espinoza Camus, C.; Rollefson, J.; Quipuscoa Silvestre, V.; Sørensen, M.K.; Víctor, P.H. La Ceja de Montaña-un Pasaje que va Desapareciendo: Estudios Interdisciplinarios en el Noreste del Perú; The National Museum of Denmark: Copenhagen, Denmark, 2010.

44. Church, W.; von Hagen, A. Chachapoyas: Cultural Development at an Andean Cloud Forest Crossroads. In Handbook of South American Archaeology; Silverman, E., Isbell, W.H., Eds.; Springer: New York, NY, USA, 2008; pp. 903-927.

45. Church, W.; Guengerich, A. Introducción: La (re)construcción de Chachapoyas a través de la historia e historiografía. In ¿Qué fue Chachapoyas? Aproximaciones interdisciplinarias en el estudio de los Andes Nororientales; Guengerich, A., Church, W., Eds.; Pontificia Universidad Católica de Perú: Lima, Peru, 2017; pp. 5-38.

46. Muscutt, K. Warriors of the Clouds: A Lost Civilization in the Upper Amazon of Peru; University of New Mexico Press: Albuquerque, NM, USA, 1998.

47. Church, W.B. Prehistoric Cultural Development and Interregional Interaction in the Tropical Montane Forests of Peru. Ph.D. Thesis, Yale University, New Haven, CT, USA, 1996.

48. Narváez Vargas, A. Kuélap: Una ciudad fortificada en los Andes nor-orientales de Amazonas, Perú. In Arquitectura y Arqueología Pasado y Futuro de la Construcción en el Peru.; Rangel, V., Ed.; Universidad de Chiclayo: Chiclayo, Peru, 1987 ; pp. 115-142.

49. Thompson, D.E. Ancient highland connections with selva and coast: evidence from Uchucmarca, Peru. In Social and Economic Organization in the Prehispanic Andes; Browman, D.L., Burger, R.L., Rivera, M.A., Eds.; BAR International Series: Oxford, UK, 1984; pp. 73-78.

50. Church, W.B.; Muscutt, K. Inticancha: A Wari Enclave in Chachapoyas? (Reopening a cold case in a cold place). In Proceedings of the 58th Annual Meeting of the Institute of Andean Studies, Berkeley, CA, USA, 6 January 2018.

51. Espinoza Soriano, W. Los Señoríos Etnicos de Chachapoyas y la Alianza Hispano-Chacha. Revista Histórica 1967, 30 , $224-333$.

52. Ruiz Estrada, A. Deslindes étnicos en la historia de Amazonas, Perú. Boletín de Arqueología PUCP 2017, 44, 41-56. [CrossRef]

53. Urban, M. Linguistic and cultural divisions in pre-Hispanic Northern Peru. Lang. Sci. 2021, 101354. [CrossRef]

54. Guevara, E.K.; Palo, J.U.; Översti, S.; King, J.L.; Seidel, M.; Stoljarova, M.; Wendt, F.R.; Bus, M.M.; Guengerich, A.; Church, W.B.; et al. Genetic assessment reveals no population substructure and divergent regional and sex-specific histories in the Chachapoyas from northeast Peru. PLoS ONE 2020, 15, e0244497. [CrossRef] [PubMed]

55. Koschmieder, K. Jucusbamba: Investigaciones arqueológicas y motivos Chachapoya en el norte de la Provincia de Luya, Departamento Amazonas, Peru; Surco: Lima, Peru, 2012.

56. Ruiz Barcellos, J. Purun Llacta y Yálape, dos Miradas para Kuélap. In Los Chachapoyas; Kauffmann Doig, F., Ed.; BCP: Lima, Peru, 2013; pp. 214-220. 
57. Schjellerup, I. Incas and Spaniards in the Conquest of the Chachapoyas. Archaeological, Ethnohistorical and Anthropological Research in North-eastern Peru; Göteborg University: Göteborg, Sweden , 1997.

58. Guengerich, A. Settlement Organization and Architecture in Late Intermediate Period Chachapoyas, Northeastern Peru. Lat. Am. Antiq. 2015, 26, 362-381. [CrossRef]

59. Crandall, J.M. El desarrollo espacial de las comunidades Chachapoyas bajo la dominación colonial inka y española. Boletín de Arqueología PUCP 2017, 23, 283-312. [CrossRef]

60. Kauffman Doig, F. (Ed.) Los Chachapoyas; BCP: Lima, Peru, 2013.

61. Guengerich, A.; Berquist, S. Earthen Terrace Technologies and Environmental Adaptation in the Montane Forests of PreColumbian Northeastern Peru. J. Field Archaeol. 2020, 45, 153-169. [CrossRef]

62. Lerche, P. Häuptlingstum Jalca: Bevölkerung und Ressourcen bei den vorspanischen Chachapoya Peru; D. Reimer: Berlin, Germany, 1986.

63. Toyne, J.M.; Church, W.B.; Luis Coronado Tello, J.; Morales Gamarra, R. Exploring imperial expansion using an isotopic analysis of paleodietary and paleomobility indicators in Chachapoyas, Peru. Am. J. Phys. Anthropol. 2017, 162, 51-72. [CrossRef]

64. Guengerich, A. Monte Viudo: Residential Architecture and the Everyday Production of Space in a Chachapoya Village. Ph.D. Thesis, University of Chicago, Chicago, USA, 2014.

65. Cieza de León, P. Crónica del Perú, Primera Parte, 2nd ed.; Pontificia Universidad Catolica del Peru: Lima, Peru, 1986.

66. Vázquez de Espinosa, A. Compendio y Descripcion de las Indias Occidentales; Biblioteca de Autores Españoles: Madrid, Spain, 1969.

67. Sarmiento de Gamboa, P. Historia Indica; Biblioteca de Autores Españoles: Madrid, Spain, 1960.

68. Narváez Vargas, A. Cerámica de Huancas-Expresión viva del Pasado; Proyecto Sierra Norte-Ministerio de Agricultura: Chachapoyas, Peru, 2014.

69. Cornejo Garcia, M.A.; Savoy, G.; Beuno Mendoza, A. El Gran Saposoa: Investigaciones y estudios. Sian 2004, 9, 12-13.

70. Nugent, D. Modernity at the Edge of Empire: State, Individual, and Nation in the Northern Peruvian Andes, 1885-1935; Stanford University Press: Palo Alto, CA, USA, 1997.

71. Zimmerer, K.S. Overlapping Patchworks of Mountain Agriculture in Peru and Bolivia: Toward a Regional-Global Landscape Model. Hum. Ecol. 1999, 27, 135-165. [CrossRef]

72. Evans, T.P.; Winterhalder, B. Modified solar insolation as an agronomic factor in terraced environments. Land Degrad. Dev. 2000, 287, 273-287. [CrossRef]

73. Plekhov, D.; Levine, E.I. Defining Suitability in Mixed Agropastoral Societies: A Case Study from Bactria in Northern Afghanistan. Environ. Archaeol. 2020, 1-16. [CrossRef]

74. Vernon, K.B.; Yaworsky, P.M.; Spangler, J.; Brewer, S.; Codding, B.F. Decomposing Habitat Suitability across the Forager to Farmer Transition. Environ. Archaeol. 2020, 1-14. [CrossRef]

75. Coughlan, M.R.; Nelson, D.R. Influences of native American land use on the colonial euro-American settlement of the South Carolina piedmont. PLoS ONE 2018, 13, e0195036. [CrossRef] [PubMed]

76. Levis, C.; Costa, F.R.C.; Bongers, F.; Peña-Claros, M.; Clement, C.R.; Junqueira, A.B.; Neves, E.G.; Tamanaha, E.K.; Figueiredo, F.O.G.; Salomão, R.P.; et al. Persistent effects of pre-Columbian plant domestication on Amazonian forest composition. Science 2017, 355, 925-931. [CrossRef]

77. OpenStreetMap Contributors. Available online: https://planet.osm.org (accessed on April 9, 2020).

78. R Core Team. R: A Language and Environment for Statistical Computing. R Foundation for Statistical Computing, Vienna, Austria, 2020.

79. Wernke, S.; VanValkenburgh, P.; Saito, A. Interregional Archaeology in the Age of Big Data: Building Online Collaborative Platforms for Virtual Survey in the Andes. J. Field Archaeol. 2020, 45, S61-S74. [CrossRef]

80. Kendall, A. The Restoration of Pre-Hispanic Agricultural Systems: Archaeology and Indigenous Technology and Rural Development; Cusichaca Trust: Belbroughton, UK, 1997.

81. Posthumus, H. Adoption of Terraces in the Peruvian Andes. Ph.D. Thesis, Wageningen Universiteit, Wageningen, The Netherlands, 2005.

82. De la Torre, C.; Burga, M.; (Eds.) Andenes y Camellones en el Perú Andino: Historia, Presente y Futuro; Consejo Nacional de Ciencia y Tecnología (CONCYTEC): Lima, Peru, 1986.

83. Joshi, A.R.; Dinerstein, E.; Wikramanayake, E.; Anderson, M.L.; Olson, D.; Jones, B.S.; Seidensticker, J.; Lumpkin, S.; Hansen, M.C.; Sizer, N.C.; et al. Tracking changes and preventing loss in critical tiger habitat. Sci. Adv. 2016, 2, e1501675. [CrossRef]

84. Kirschbaum, D.; Stanley, T. Satellite-Based Assessment of Rainfall-Triggered Landslide Hazard for Situational Awareness. Earth's Future 2018, 6, 505-523. [CrossRef]

85. Liao, C.; Jung, S.; Brown, D.G.; Agrawal, A. Spatial patterns of large-scale land transactions and their potential socioenvironmental outcomes in Cambodia, Ethiopia, Liberia and Peru. Land Degrad. Dev. 2020, 31, 1-11. [CrossRef]

86. World Resources Institute. Global Forest Watch; 2014.

87. Matthews-Bird, F.; Valencia, B.G.; Church, W.; Peterson, L.C.; Bush, M. A 2000-year history of disturbance and recovery at a sacred site in Peru's northeastern cloud forest. Holocene 2017, 27, 1707-1719. [CrossRef]

88. Bush, M.B.; Mosblech, N.A.S.; Church, W. Climate change and the agricultural history of a mid-elevation Andean montane forest. Holocene 2015, 25, 1522-1532. [CrossRef] 
89. VanValkenburgh, P.; Cushman, K.C.; Butters, L.J.C.; Vega, C.R.; Roberts, C.B.; Kepler, C.; Kellner, J. Lasers Without Lost Cities: Using Drone Lidar to Capture Architectural Complexity at Kuelap, Amazonas, Peru. J. Field Archaeol. 2020, 45, S75-S88. [CrossRef]

90. Frolking, S.; Milliman, T.; Palace, M.; Wisser, D.; Lammers, R.; Fahnestock, M. Tropical forest backscatter anomaly evident in SeaWinds scatterometer morning overpass data during 2005 drought in Amazonia. Remote Sens. Environ. 2011, 115, 897-907. [CrossRef]

91. Frolking, S.; Hagen, S.; Braswell, B.; Milliman, T.; Herrick, C.; Peterson, S.; Roberts, D.; Keller, M.; Palace, M. Evaluating multiple causes of persistent low microwave backscatter from Amazon forests after the 2005 drought. PLoS ONE 2017, 12, e0183308. [CrossRef]

92. Milien, E.J.; Rocha, K.d.S.; Brown, I.F.; Perz, S.G. Roads, deforestation and the mitigating effect of the Chico Mendes extractive reserve in the southwestern Amazon. Trees For. People 2021, 3, 100056. [CrossRef]

93. Barber, C.P.; Cochrane, M.A.; Souza, C.M.; Laurance, W.F. Roads, deforestation, and the mitigating effect of protected areas in the Amazon. Biol. Conserv. 2014, 177, 203-209. [CrossRef]

94. Laurance, W.F.; Albernaz, A.K.M.; Schroth, G.; Fearnside, P.M.; Bergen, S.; Venticinque, E.M.; Da Costa, C. Predictors of deforestation in the Brazilian Amazon. J. Biogeogr. 2002, 29, 737-748. [CrossRef]

95. Pain, A.; Marquardt, K.; Khatri, D. Secondary Forests and Agrarian Transitions: Insights from Nepal and Peru. Hum. Ecol. 2021. [CrossRef]

96. Polk, M.H.; Mishra, N.B.; Young, K.R.; Mainali, K. Greening and Browning Trends across Peru's Diverse Environments. Remote Sens. 2020, 12, 2418. [CrossRef]

97. Salas, D. Andenes, agrosistema frágil. In Conservación y Abandono de Andenes; Llerena, C.A., Inbar, M., Benavides, M.A., Eds.; Universidad Nacional Agraria La Molina, Universidad de Haifa: Lima, Peru, 2004; pp. 23-44.

98. Posthumus, H.; Stroosnijder, L. To terrace or not: The short-term impact of bench terraces on soil properties and crop response in the Peruvian Andes. Environ. Dev. Sustain. 2010, 12, 263-276. [CrossRef]

99. Benavides, M. Andenes y riego en el Perú: un análisis de informes coloniales y republicanos. In Conservación y Abandono de Andenes; Llerena, C.A., Inbar, M., Benavides, M., Eds.; Universidad Nacional Agraria La Molina, Universidad de Haifa: Lima, Peru, 2004; pp. 51-65.

100. Shanee, S.; Shanee, N.; Lock, W.; Espejo-Uribe, M.J. The Development and Growth of Non-Governmental Conservation in Peru: Privately and Communally Protected Areas. Hum. Ecol. 2020, 48, 681-693. [CrossRef] 